\title{
まっすぐな円管内の乱流旋回流の特性* （旋回の減衰に伴う角運動量の変化）
}

\author{
畠沢政保*1

\section{Characteristics of Turbulent Swirling Flow in a Straight Pipe (Change in Angular Momentum with Swirl Decay)}

\author{
Masayasu HATAZAWA*2 \\ ${ }^{* 2}$ Department of Engineering Science, Junior College of Nihon University, \\ 7-24-1 Narashinodai, Funabashi-shi, Chiba, 274-8501 Japan
}

\begin{abstract}
The swirl effects on the angular momentum distribution of turbulent swirling flow in a straight pipe are described. When the swirl strength increases, the axial velocity decreases in the central region and its distribution becomes constant in the annular region of the pipe, except in the boundary layer adjacent to the pipe wall. Tangential velocity induces the formation of a combined vortex similar to the Rankine vortex which is a solid vortex in the central domain and a free vortex in the annular region of the pipe. Although factors that affect flow, such as the contours of the swirling angle, axial and tangential velocities and fluctuation velocity, have been discussed previously by the authors, their analyses have not yet been conducted. The local angular momentum at radius, $r$, in the pipe is employed in this study. As a result, the local angular momentum downstream does not change in the central region but decreases in the annular region of the pipe. It is suggested that most of the swirl decay in a straight pipe depends on the viscous forces that occur either between fluids or between a fluid and the pipe wall in the annular region of the pipe.
\end{abstract}

Key Words : Pipe Flow, Turbulent Flow, Swirling Flow, Angular Momentum, Swirl Decay

\section{1. 緒言}

旋回を伴う円管流れでは, 旋回強度の増加とともに 管中央部において軸速度が減少し, 遂に逆流が生じ る.また，それより外側の管壁に至る円環流領域で軸 速度分布が平たん化するなど, 流れの様相が無旋回円 管流れと大きく異なる。畠沢・小松(1)(2), 畠沢(3)(4) は 旋回を伴う円管流れの特性を明らかにすべく一連の研 究を行っている. その一環として, 旋回を伴う円管流 れにおける逆流の発生条件を, 特性半径(旋回によっ て流体が管中央部から管壁側へ排除された領域を排除 半径と定義した) および管壁近傍の旋回角 $\Theta_{s w}$ (管中心 から管半径の 0.95 倍離れた半径位置における流れと 管軸を含む面のなす角度であり, 畠沢らは一連の研究 において旋回強度の表示に採用している)を用いて分 析している(1) (3). したがって, 本報告においても，旋 回強さの表示に，管壁近傍の旋回角 $\Theta_{s w}$ を採用してい る. また, 接線速度分布は旋回発生装置の影響が残る 管入口直後を除き, 下流側のほとんどの位置において 管中央部で渦度のある強制渦であり, それより外側の

* 原稿受付 2004 年 12 月 21 日.

*1 正員, 日本大学短期大学部基礎工学科(更274-8501 船橋市 習志野台 7-24-1).

E-mail : hatazawa@eme.cst.nihon-u.ac.jp
管壁に及ぶ範囲では渦度のない自由渦となる組合せ渦 の様相を呈している.それら双方の領域についても畠 沢・小松は別の特性半径(軸速度および接線速度が最 大となる半径位置と定義した)を用いて確認してい る(1). 従来, 旋回を伴う円管流れにおいて, 旋回角, 軸速度・接線速度および乱れ速度はともにそれらの等 値線図あるいは下流方向各位置における半径方向分布 によって検討されていた (1)〜(3) が, 軸速度および接線 速度等の半径方向あるいは下流方向への変化を個別に 観察するだけでは, 円管内の旋回の減衰機構を解明す るには不十分である。以上の理由から，本報告では， まっすぐな円管内における旋回の減衰機構をよりいっ そう明確にするために角運動量そのものの変化に着目

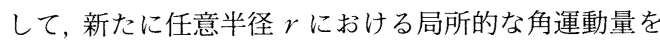
提案し, それらの半径方向および下流方向への変化に ついて検討した. その結果, 各半径位置における局所 的な角運動量が, 管中央部においては下流方向にわず かに減少するものの, ほとんど変化せずに一定であ る.一方, それより外側の管壁までに及ぶ円環流領域 においては下流方向に大きく減少することがわかっ た.これらのことは, 旋回を伴う円管流れにおいて, 管壁近傍の旋回角で表示された旋回の減衰が, 管中央 部における強制渦領域の流体同士の摩擦によるより 
もむしろそれより外側，管壁側に及ぶ自由渦領域に おける流体同士あるいは流体と管壁の間の粘性力に大 きく依存していることを示唆している.ここでは, 旋 回強さの減衰に伴って生じる角運動量の変化を新しく 提案した局所角運動量を用いて検討した結果について 報告する。

\section{2. 実験装置および実験方法}

図 1 に円管内旋回流実験装置 ${ }^{(1)}$ (3) を示す。空気は 旋回発生装置を介して内径 $154.5 \mathrm{~mm}$, 長さ $9.5 \mathrm{~m}$ の 透明アクリル管に吸い込まれる。旋回発生装置には 2 種類のものを採用した。一つは，より強い旋回流を発 生させるために接線方向の 3 箇所にベルマウス状入口 部をもつ透明アクリル管(内径 $49.3 \mathrm{~mm}$, 長さ 200 $\mathrm{mm}$ )を枝管として設けた形(ここでは接線流入形とい う)であり，もう一つは，18枚の案内羽根(長さ 100 $\mathrm{mm}$, 最大厚さ $15 \mathrm{~mm}$ であり対称翼形断面 （NACA 63 ${ }_{2}$ A 015）を有する）を円形の平行平板間に放 射状に配した形(ここでは案内羽根流入形という)であ る、案内羽根の角度を調整することで管入口部におけ る旋回強度を任意に変えることができる．流れの方向 ならびに速度は二孔円筒形ピトー管(直径 $4 \mathrm{~mm}$ ，長 さ $230 \mathrm{~mm}$, 測定孔径 $0.3 \mathrm{~mm}$ )を用いて測定した。あ わせて I 形熱線プローブおよび定温度形熱線風速計を
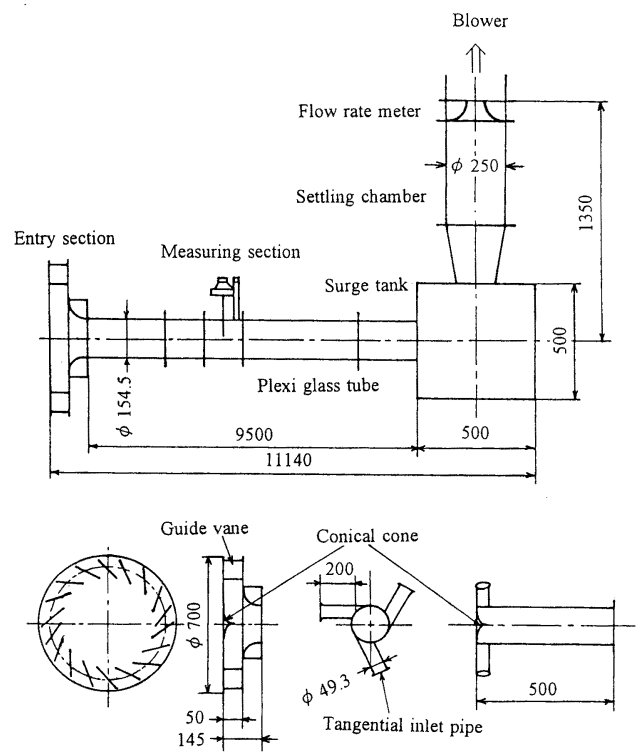

(1) Guide vanes type

(2) Tangential inlet pipes type Employed swirlers

unit : $\mathrm{mm}$

Fig. 1 Schematic diagram of the experimental apparatus
用いて平均速度および乱れ速度の測定を行った. 案内 羽根の角度 $\Theta_{v}$ は $0,30,45,60^{\circ}$ に設定したが, 接線 流入形の場合は, 管入口部の旋回強度が案内羽根角 $\Theta_{v}=60^{\circ}$ 以上に相当する(4). な扔, 測定位置は管入口 からの距離 $x$ が $0.94 D$ より $62.2 D(D$ は管直径であ る)までの 20 箇所とした. また, 管直径と断面平均速 度を基準とするレイノルズ数 Re が $4 \times 10^{4}$ から $10^{5}$ までの範囲で測定を行ったが, ここでは入口が案内羽 根流入形であり, かつ $R e=10^{5}$ の条件で得られた測定 結果について検討する.

\section{3. 実験結果および検討}

\section{$3 \cdot 1$ 旋回減衰の従来の表示法}

$3 \cdot 1 \cdot 1$ スワール数による旋回強度の表示 従来, 旋回を伴う円管流れにおける旋回強さは，任意断面に おける角運動量を軸方向運動量および代表寸法として の管半径 $R$ で除して無次元化した, スワール数 $m^{(5)}$ で表示されてきた。

$$
m=\frac{\int_{0}^{R} \rho U V r 2 \pi r d r}{R \int_{0}^{R} \rho U^{2} 2 \pi r d r}=\frac{\int_{0}^{R} U V r^{2} d r}{R \int_{0}^{R} U^{2} r d r}
$$

ここで， $r$ は管中心からの任意半径， $R$ は管半径, $U$ は $r$ における軸速度, $V$ は $r$ におる接線速度, $\rho$ は作動流体の密度である。

しかし, 式（1）における角運動量および軸方向運動 量はともに管中心より管壁までの管断面全域にわたる 積分量である. そ机ゆえ, 半径 $r$, 幅 $d r$ の円環状の 部分を通過する流体が有する角運動量, 軸方向運動量 はともに管壁近傍に近付くほど急激に増加する，その 結果, スワール数 $m$ は管壁近傍の流れの状態に大き く影響される，以上のことを考慮に入れて，管内旋回 流の旋回強度を表示する一つの方法として, 畠沢・小 松は管壁近傍の流れの状態をよく表す管壁近傍の旋回 角 $\Theta_{s w}(r / R=0.95$ における流れと管軸を含む平面と のなす角度)を提案し, その有意性を確認してい

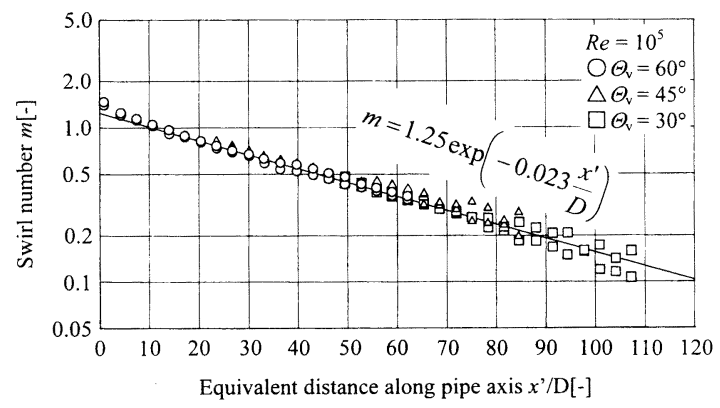

Fig. 2 Change in swirl number downstream 
$ろ^{(1) \sim(3)}$.

図 2 に $e^{2}=10^{5}$ におけるスワール数 $m$ の下流方向 への変化を示す. なお, 管入口からの相当距離 $x^{\prime}$ は, 案内羽根角の違いにかかわらず, 測定結果から得られ た $x / D$ に対するスワール数 $m$ の変化が等しくなるよ うに案内羽根角 $\Theta_{v}=60^{\circ}$ で得られた結果と重ねて座 標を合せた. その結果, 案内羽根角 $\Theta_{v}=45^{\circ}$ では, $\Theta_{v}$ $=60^{\circ}$ のときの $3146 \mathrm{~mm}$ 以降で, 案内羽根角 $\Theta_{v}=$ $30^{\circ}$ では, $\Theta_{v}=60^{\circ}$ の場合の $7645 \mathrm{~mm}$ 以降でスワー ル数の下流方向変化が一致した. 本研究では, 各案内 羽根角において管入口部からの距離を $x$ としている. したがって, 入口部からの相当距離 $x^{\prime}$ を, 案内羽根角 $\Theta_{v}=45^{\circ}$ では $x+3146 \mathrm{~mm}, \Theta_{v}=30^{\circ}$ では $x+7645$ $\mathrm{mm}$ とした. スワール数 $m$ は下流方向へ指数関数的 に減少しており，管入口部における旋回強度の相違に かかわらず，式（2）でよく近似できることがわかっ た。

$$
m=1.25 \exp \left(-0.023 \frac{x^{\prime}}{D}\right)
$$

ここで, $D$ は管直径, $x^{\prime}$ は管入口からの相当距離で ある。

$3 \cdot 1 \cdot 2$ 管壁近傍の旋回角による旋回強度の表示

図 3 は $R e=10^{5}$, 半径 $r / R=0.95$ における旋回角 $\Theta_{s w}$ の下流方向への変化を示す.下流方向への距離 $x^{\prime}$ は図 2 に示すスワール数 $m$ の下流方向への変化と 同様に，管入口部の案内羽根角に関係なく $\Theta_{s w}$ が重な るようにして調整してある. 管入口部の旋回強度が異 なるにもかかわらず, $\Theta_{s w}$ の下流方向への変化は式 (3)，（4）によく一致しており， $x^{\prime} / D=60$ 以降におい て下流方向への $\Theta_{s w}$ の減少する度合がいっそう増大 することを示す。

$$
\begin{array}{r}
0<\frac{x^{\prime}}{D}<60 \text { では } \Theta_{s w}=55 \exp \left(-0.0135 \frac{x^{\prime}}{D}\right) \\
\cdots \cdots \cdots \cdots( \\
60<\frac{x^{\prime}}{D} \text { では } \Theta_{s w}=70 \exp \left(-0.0175 \frac{x^{\prime}}{D}\right) \cdots(
\end{array}
$$

$3 \cdot 2$ 局所角運動量による旋回の減衰の表示 妹

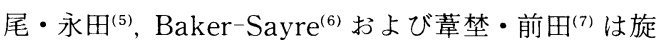
回を伴う円管流れの角運動量を評価する際に, 軸速度 が管断面全体にわたり一様であり, 接線速度のみが半 径方向に変化すると仮定した無次元角運動量 $V r / \bar{U} R$ を採用している。確かに $V r / \bar{U} R$ は任意半径における 渦度の有無を確認するには有効である。しかし, 旋回 を伴う円管流れでは, 旋回強度が増すにつれて管中央 部において軸速度が減少し, 遂に逆流が生じる.さら に管壁近傍の境界層内においても軸速度が大きく減少

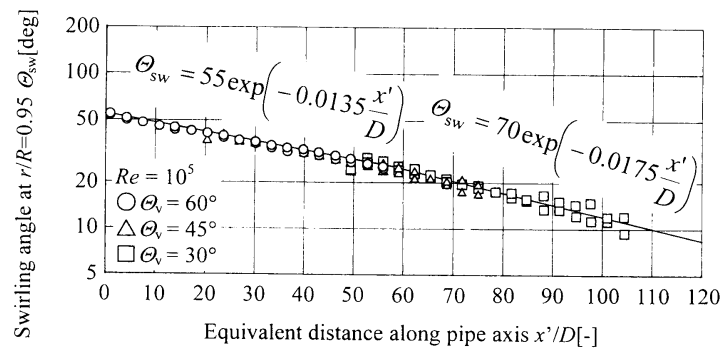

Fig. 3 Change in swirling angle at $r / R=0.95$ downstream

するなど, 軸速度が半径方向に大きく変化する(1)こと から，軸速度が管断面全体にわたって一様に分布する 仮定がもはや成立せず, $V r / \bar{U} R$ だけで円管内におけ る角運動量の半径方向および下流方向の変化を評価す るには不十分であると思われる。 また，式(1)で表示 されるスワール数 $m$ は, 管断面全体にわたる角運動 量流量を軸方向運動量流量と代表寸法である管半径 $R$ の積で除した無次元数であり, どの半径位置で角運 動量が下流方向に減少しているのか不明りょうであ る.よって, ここでは, 旋回を伴う円管流れにおける 旋回の減衰機構において, 流体の有する角運動量が管 内のどの半径位置において著しく減衰するのかをより いっそう明確にするために, 以下に示す任意半径 $r$ に おける局所的な角運動量を採用して, それらの半径方 向および下流方向への変化を検討する.

円管内において任意半径 $r$ で半径方向に微小幅 $d r$ を有する円環状の微小部分を通過する流体がもつ角運 動量 $M_{a}$ は式（ 5 ) で表される.

$$
M_{a}=\rho U V r 2 \pi r d r=\rho U V 2 \pi r^{2} d r
$$

さらに, 円管の軸と直角な断面における軸方向の運 動量 $M$ は式（6)で表される.

$$
M=\int_{0}^{R} \rho U^{2} 2 \pi r d r
$$

したがって, 任意半径 $r$, 幅 $d r$ の円環状の微小部 分において流体のもつ角運動量と軸方向運動量の比は 式( 7 )で表される.

$$
\frac{M_{a}}{M}=\frac{\rho U V r 2 \pi r d r}{\int_{0}^{R} \rho U^{2} 2 \pi r d r} \approx \frac{\rho U V r 2 \pi r d r}{2 \pi \rho \bar{U}^{2} \frac{R^{2}}{2}}=\frac{2 U V r^{2} d r}{\bar{U}^{2} R^{2}}
$$

ここで, $\bar{U}$ は断面平均速度である.

よって,ここでは局所的な角運動量の無次元量とし て $m_{a}^{\prime}$ を新たに式 $(8)$ で定義する.

$$
m_{a}^{\prime}=\frac{U V r}{\bar{U}^{2} R}
$$

すなわち, $m_{a}^{\prime}$ は任意半径 $r$ において, 管軸と直角 


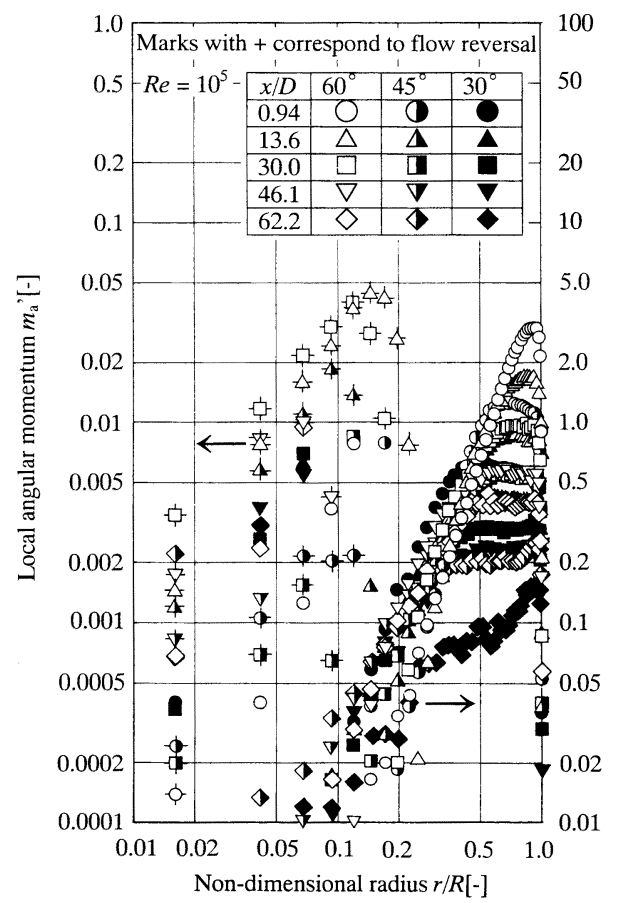

Fig. 4 Local angular momentum distribution

な単位面積を通過する流体がもつ角運動量流量を, 代 表寸法である管半径 $R$ と管軸と直角な単位面積を断 面平均速度 $\bar{U}$ で通過する流体が有する軸方向運動量 流量の積で除した無次元数である.したがって, 局所 角運動量 $m_{a}^{\prime}$ は局所スワール数 (以降, 図中には Local angular momentum と表示する)に相当する.

$3 \cdot 2 \cdot 1$ 局所角運動量の半径方向分布 図 4 は $R e=10^{5}$ の場合, 管入口部から下流方向への代表的な 位置に打ける局所角運動量 $m_{a}^{\prime}$ の半径方向分布を示 す.なお，図 4 中の十を付した印は， $m_{a}^{\prime}$ が負，すなわ ち軸速度が負であり逆流していることを表す。したが って,この場合の $m_{a}^{\prime}$ の読みは縦座標に -1 を乗じた ものとする．また， $m_{a}^{\prime}$ の值は図 4 中に矢印で示すよ うに管中央部では左の座標を，それより外側の管壁ま での円環流領域では右の座標で表示する。案内羽根角 $\Theta_{v}=60^{\circ}$ の場合, 管入口直後 $x / D=0.94$ では, 管中央 より管壁近傍に及ぶ広い範囲で, 半径の増加とともに $m_{a}^{\prime}$ が増加しており，管中央部に逆流が見られない. しかし，それょり下流では $m_{a}^{\prime}$ の分布する領域が大き く二つに分けられる。すなわち，管中央部 $0<r / R<$ 0.2 では, 下流方向への位置が異なるにもかかわらず, $m_{a}^{\prime}$ の半径方向の分布がほぼ一致しており,また逆流 も見られる.さらに $0.2<r / R<0.4$ では，管入口部か らの距離の相違によらず $m_{a}^{\prime}$ の半径方向分布がほとん

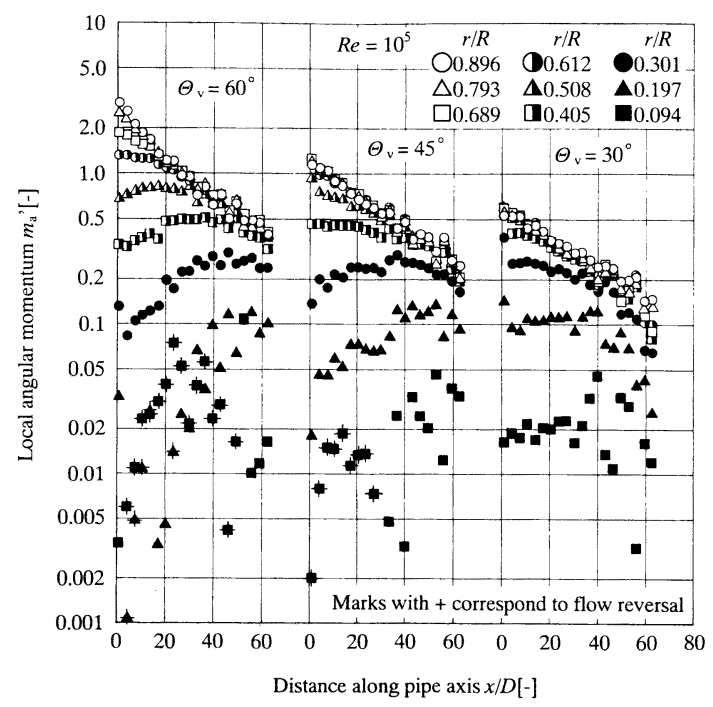

Fig. 5 Change in local angular momentum downstream

ど一致している.一方, $0.4<r / R<1$ の範囲において は, $x / D$ の增加に伴って, $m_{a}^{\prime}$ の最大值が減少すると ともに，その半径方向分布がよりいっそう平たん化し ている.

案内羽根角 $\Theta_{v}=45^{\circ}$ の場合, 管中央部において管入 口直後より $x / D=46.1$ までの範囲で逆流が見られ, その半径方向の領域は下流に位置するに従って次第に 狭くなっており， $x / D=62.2$ ではもはや逆流が見られ ない，また，それより外側の円管壁近傍に及ぶ円環流 領域では, $x / D$ の増加とともに $m_{a}^{\prime}$ が減少し,さらに その分布が $\Theta_{v}=60^{\circ}$ の場合に比べていっそう平たん 化している.

案内羽根角 $\Theta_{v}=30^{\circ}$ の場合, 管中央部に逆流が見ら れず，また $m_{a}^{\prime}$ の分布もほぼ一致している。管壁側の 円環流領域では, $m_{a}^{\prime}$ が減少し，その分布が平たん化 する.しかし, $x / D=62.2$ では旋回がよりいっそう減 衰して抢り,さらに $m_{a}^{\prime}$ の半径方向分布が他の位置に おける分布と大きく異なっている。このことに関して 畠沢は別に行った実験によって以下のことを確認して いる，十分下流に位置し旋回が隇衰するに従って，旋 回角が減少し，かつ半径方向にほほ均一に分布する。 また，管中央部において減少していた軸速度も徐々に 回復するとともに, 軸速度の減少する範囲も次第に狭 くなり，無旋回円管流れの軸速度分布に近付く．さら に, 接線速度も大幅に減少し, かつその分布も次第に 強制渦の様相を呈するなど, 流れの状態がそれより上 流に打けるランキンの組合せ渦から, 強制渦形へと大 きく変化している(1). したがって $x^{\prime} / D=62.2$ におけ 
る $m_{a}^{\prime}$ の変化が上流の他の位置における $m_{a}^{\prime}$ の変化と 異なるのは，これらのことに起因すると考えられる.

$3 \cdot 2 \cdot 2$ 各半径位置における局所角運動量の下流方 向への変化 図 5 は $R e=10^{5}$ の場合の各半径にお ける局所角運動量 $m_{a}^{\prime}$ の下流方向への変化を示す。な お, 図 5 中で+を付した印は, $m_{a}^{\prime}$ が負, すなわち軸速 度が負であり逆流していることを示す.したがって， この場合の $m_{a}^{\prime}$ の読みは, 図 4 と同様に, 縦座標に -1 を乗じたものとする. 案内羽根角 $\Theta_{v}=60^{\circ}$ の場合, 管 壁近傍 $0.689<r / R<0.896$ では, $m_{a}^{\prime}$ が下流方向に大 幅に減少しているが, $r / R=0.612,0.508$ では管入口 より $x / D$ が 35 まで $m_{a}^{\prime}$ がほぼ一定であり, $35<x / D$ では $m_{a}^{\prime}$ が $x / D$ の増加とともに減少する. $r / R=$ 0.405 では $x / D$ が増加しても $m_{a}^{\prime}$ はほぼ一定であり, $0.094<r / R<0.301$ では $x / D$ の増加に伴って $m_{a}^{\prime}$ が わずかに増加している.

案内羽根角 $\Theta_{v}=45^{\circ}$ の場合, $0.508<r / R<0.896$ で は $x / D$ の増加に伴って $m_{a}^{\prime}$ が減少する。 $r / R=0.405$, 0.301 では $x / D$ が増加しても $m_{a}^{\prime}$ がほぼ一定であり, $0.094<r / R<0.301$ では $x / D$ の増加とともに $m_{a}^{\prime}$ が わずかに増加している。

案内羽根角 $\Theta_{v}=30^{\circ}$ の場合, $0.405<r / R<0.896$ で は $x / D$ の増加とともに $m_{a}^{\prime}$ が減少する. 一方, 0.094 $<r / R<0.301$ では $x / D$ が増加しても $m_{a}^{\prime}$ がほとんど 変化しない.

$3 \cdot 2 \cdot 3$ 局所角運動量の下流方向変化(管入口部から の相当距離による表示) 図 6 には図 2 および図 3 で示したスワール数 $m$ および管壁近傍の旋回角 $\Theta_{s w}$ の下流方向への変化の表示法と同様に, 案力羽根角が 異なる場合, $r / R=0.896$ における局所角運動量 $m_{a w}^{\prime}$ の下流方向への変化が重なるように位置を調整して求 めた管入口部からの相当距離 $x^{\prime} / D$ と各半径における 局所角運動量 $m_{a}^{\prime}$ の関係を示す.なお, 図 6 中で印 に+を付したものは, 軸速度が負であり逆流を生じて いるものであり, $m_{a}^{\prime}$ の読みは, 縦座標にー1を乗じた ものとする．管入口部の旋回強さの違いにかかわら ず, 各半径における $m_{a}^{\prime}$ の下流方向への変化には相似 性が見られる．また $0.689<r / R<0.896$ の管壁近傍 では $x^{\prime} / D$ の増加とともに $m_{a w}^{\prime}$ が大幅に減少してお り, その下流方向への変化は $x^{\prime} / D=20$ 以降で式 (9) でよく近似できる.

$$
m_{a w}^{\prime}=1.8 \exp \left(-0.022 \frac{x^{\prime}}{D}\right)
$$

さらに, $m_{a}^{\prime}$ は $r / R=0.612$ では $x^{\prime} / D=20$ まで, $r / R=0.508$ では $x^{\prime} / D=50$ まで, $r / R=0.405$ では $x^{\prime} / D=70$ まで $x^{\prime} / D$ が増加してもほぼ一定であり, そ

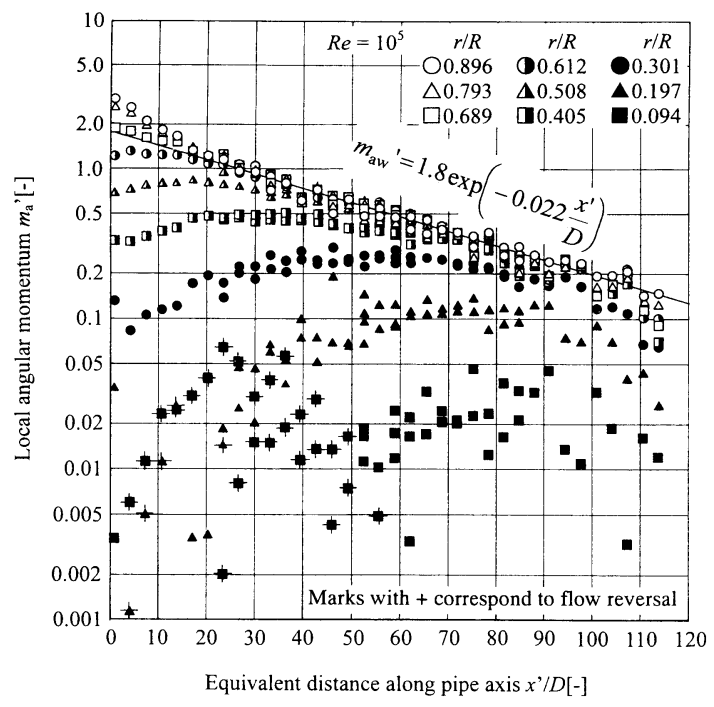

Fig. 6 Change in local angular momentum downstream with equivalent distance along pipe axis

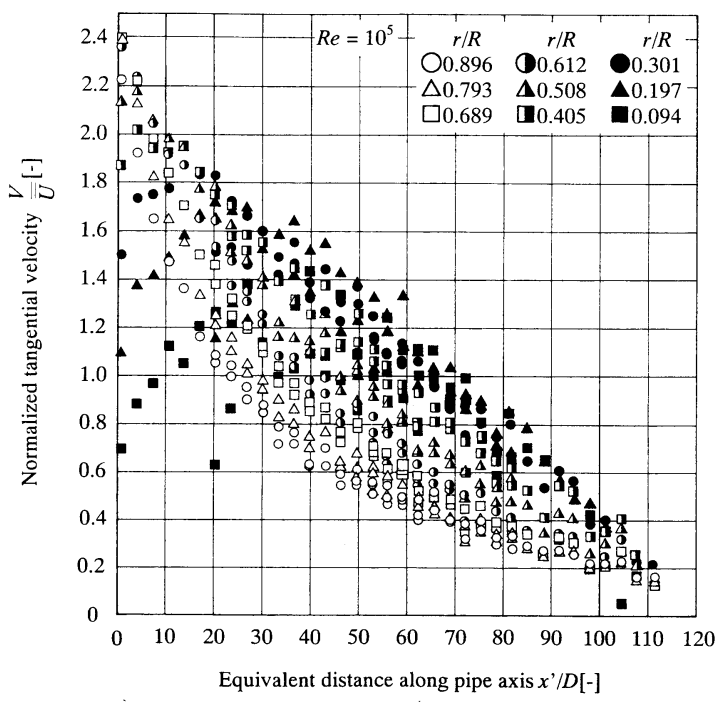

Fig. 7 Change in non-dimensional tangential velocity downstream with equivalent distance along pipe axis

れより下流では $m_{a}^{\prime}$ は式 $(9)$ で表される近似線にほと んど一致しており, $m_{a}^{\prime}$ は下流方向に指数関数的に減 少する.また, $r / R=0.301$ では $x^{\prime} / D$ が増加しても $m_{a}^{\prime}$ がほぼ一定の值を保ち, $r / R=0.197,0.094$ では $x^{\prime} / D$ の増加とともに $m_{a}^{\prime}$ がわずかに増加している.

$3 \cdot 2 \cdot 4$ 採用した局所角運動量の有為性 図 7 に 管入口部からの相当距離 $x^{\prime} / D$ と各半径位置における 


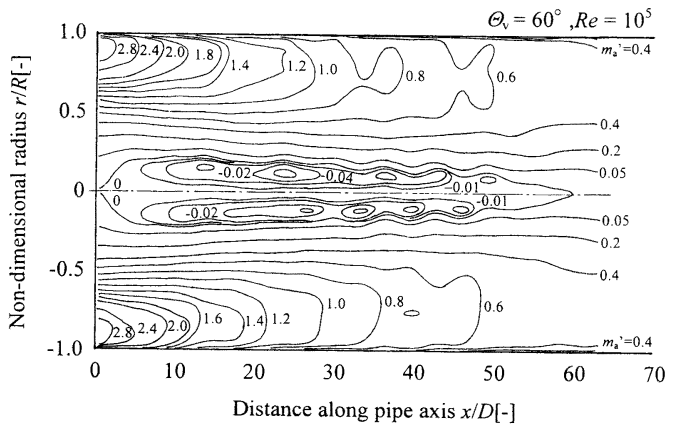

Fig. 8 Contour of local angular momentum $\left(\Theta_{v}=60^{\circ}\right)$

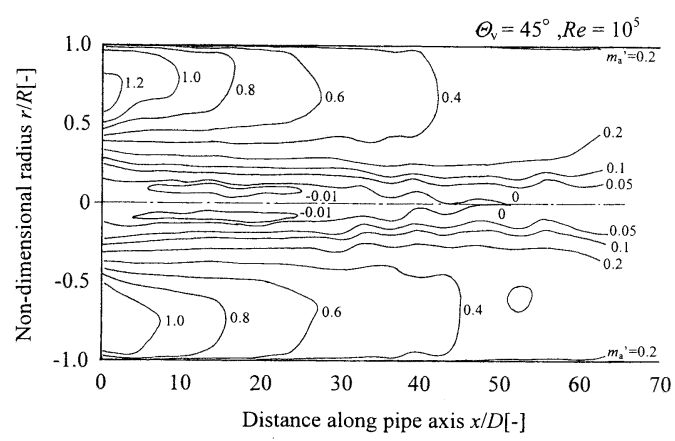

Fig. 9 Contour of local angular momentum $\left(\Theta_{v}=45^{\circ}\right)$

断面平均速度で無次元化した接線速度 $V / \bar{U}$ の関係を 示す. 相当距離が短いとき，管中央部の強制渦領域が 非常に広く，下流に位置するに従って，自由渦の領域 が次第に広がっている．また，管壁近傍の接線速度が 下流に位置するに従い，減衰しているのがわかる.し かし，接線速度の減衰で表示した各半径位置での旋回 の隇衰は, 図 6 で示した局所角運動量の下流方向変化 に比べて明りょうではない。さらに，無次元化した接 線速度分布は，管内旋回流の渦の形状(強制渦あるい は自由渦)を判断する，あるいは，下流への減衰を概観 するには有用であるが, 各半径位置における接線速度 の変化が旋回の減衰に与える影響が不明りょうであ る. 一方, 新しく提案した局所角運動量では, 各半径 位置での角運動量流量の減衰が明りょうである。した がって，管内における旋回の減衰機構を検討する場合, 局所角運動量がより有為であると考えられる.

$3 \cdot 2 \cdot 5$ 局所角運動量の下流方向変化(等值線図によ る表示） 図 8 に $R e=10^{5}, \Theta_{v}=60^{\circ}$ における局所角 運動量 $m_{a}^{\prime}$ の等值線図を示す。管中央部には $m_{a}^{\prime}$ が負 の領域があり，広い範囲で逆流しているのがわかる. また，管中央部において $m_{a}^{\prime}$ は下流方向にわずかに減

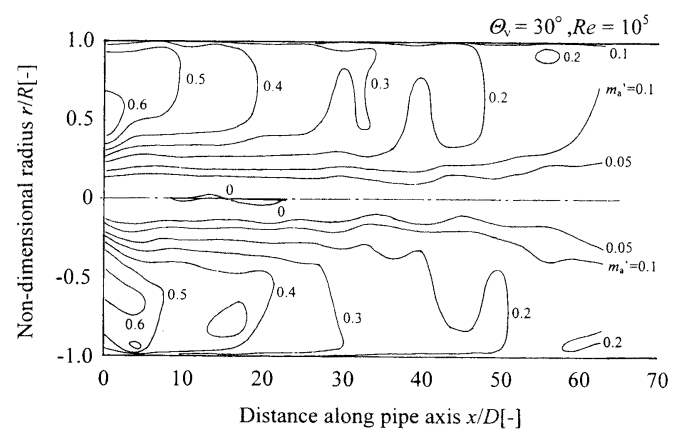

Fig. 10 Contour of local angular momentum $\left(\Theta_{v}=30^{\circ}\right)$

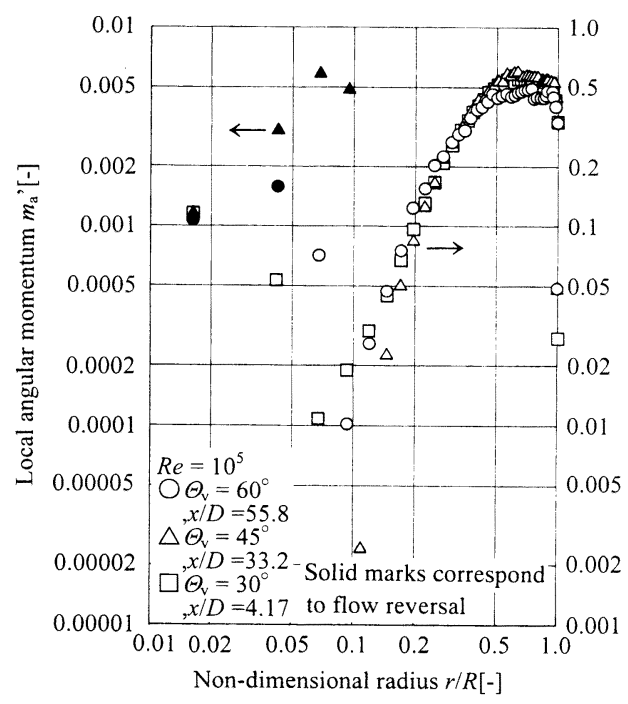

Fig. 11 Similarity of local angular momentum distribution

少する. $0.2<r / R<0.4$ の領域では $m_{a}^{\prime}$ が下流方向に ほとんど変化しない. しかし，それより外側 $0.4<$ $r / R<1.0$ の領域では下流に位置するに従って $m_{a}^{\prime}$ が 大幅に減少している.

図 9 は $R e=10^{5}, \Theta_{v}=45^{\circ}$ における局所角運動量 $m_{a}^{\prime}$ の等值線図を示す. $0<r / R<0.3$ の領域では $m_{a}^{\prime}$ が下 流方向にほとんど変化しないが, 管中央部の逆流域が 下流方向に次第に狭まり, $x / D$ が 50 以降では逆流域 が見られない. また, $0.3<r / R<1.0$ では下流に位置 するに従って $m_{a}^{\prime}$ が減少する.

図 10 は $R e=10^{5}, \Theta_{v}=30^{\circ}$ に打ける局所角運動量 $m_{a}^{\prime}$ の等值線図を示す。管中央部 $0<r / R<0.2$ にはも はや逆流域が見られず，各半径位置における $m_{a}^{\prime}$ が下 流方向にほとんど変化しない。しかし，それより外側 の管壁までに至る円環流領域では下流に位置するに従 って各半径位置の $m_{a}^{\prime}$ が減少している. 
図 8 から図 10 より， $m_{a}^{\prime}$ の等值線図の分布は，管軸 に対してほぼ対称のように見える.またこここでは示 していないが, 案内羽根角の違いによらず $r / R=$ 0.896 における無次元局所角運動量 $m_{a w}^{\prime}$ が等しくな るように $m_{a}^{\prime}$ の等值線図を重ねたところ, 図 6 に示す 各半径位置における局所角運動量の下流方向への変化 と同様に $m_{a}^{\prime}$ の等值線図にも相似性があることが確認 できた。

畠沢・小松は, 先に旋回角, 軸速度および接線速度 を等值線図で表しており, 旋回角, 軸速度および接線 速度がともに管中央部では下流方向にほとんど変化し ないが, 円環流領域で下流方向に大きく変化する。ま た, 十分下流に位置し, かつ旋回が減衰すると軸速度 分布が次第に無旋回円管流れの分布に近付くことをす でに確認している(1). それに加えて, 本研究で採用し た局所角運動量を用いて旋回流を解析することで，ま つすぐな円管内の旋回の減衰機構をよりいっそう明ら かにできることがわかった。

$3 \cdot 2 \cdot 6$ 局所角運動量の半径方向分布の相似性

図 11 は $R e=10^{5}$, 管入口部の旋回強度が異なる場 合であり, かつ $r / R=0.896$ における局所角運動量 $m_{a w}^{\prime}$ がほぼ等しい場合の $m_{a}^{\prime}$ の半径方向分布を比較し て示す. $m_{a}^{\prime}$ の半径方向分布が管内全域にわたってほ とんど一致しており, 局所角運動量の半径方向の分布 が, 管壁近傍のみならず, その他のほぼすべての半径 位置で相似であることがわかる.

以上の結果より, 新しく採用した局所角運動量 $m_{a}^{\prime}$ が管中央部では下流方向にあまり変化せずにほぼ一定 である.一方，それより外側の管壁までに至る円環流 領域では $m_{a}^{\prime}$ が下流方向に大幅に減少している.した がってまっすぐな円管内において, 旋回の減衰, すな わち管壁近傍の旋回角の減衰は, 管中央部の強制渦領 域における流体同士の摩擦よりも，むしろそれより外 側の管壁に至る円環流領域における流体同士および流 体と管壁との間の粘性力に大きく依存すると考えられ る.

\section{4. 結}

まっすぐな円管内の乱流旋回流において, 旋回強さ
の表示に管壁近傍の旋回角を採用した．また，旋回の 減衰機構を解明すべく, 新たに局所角運動量を提案し, 解析した. その結果, 明らかになったことは以下のと おりである。

（1）旋回を伴う円管流れにおいて, 旋回の強さの 減衰が, 管壁近傍の旋回角の減衰でよく表されること を再確認できた。

（2）新たに採用した局所的な角運動量を用いて旋 回流を検討することで, 円管内の旋回の減衰機構をよ りいっそう明らかにできる。

（3）管壁近傍の局所角運動量が等しい場合, 管入 口部の旋回強度の違いによらず, 各半径での局所角運 動量の下流方向への変化は相似である.

（4）局所角運動量は管中央部で減少しにくく，そ の外側の管壁に至る円環流領域では下流方向に大きく 減少する.

（5）円管内の旋回の減衰, すなわち管壁近傍の旋 回角の減衰は, 管中央部の流体同士の摩擦よりも, む しろ円環流領域の流体同士および流体と管壁との間の 粘性による摩擦力に強く依存する.

\section{文献}

（1）畠沢政保・小松安雄, 真っ直ぐな円管内の乱流旋回流の 特性一流れの相似性と逆流の発生条件一, ながれ， 16-2 (1997), 128-138.

（2）畠沢政保・小松安雄, 真っ直ぐな円管内の乱流旋回流の 特性一旋回による境界層発達の抑制効果一, ながれ, 16-2 (1997), 139-148.

（3）畠沢政保，まっすぐな円管内の乱流旋回流の特性一旋回 のピッチと圧力損失一, ながれ, 19-2 (2000), 129-138.

（4）香沢政保, 真っ直ぐな円管内の乱流旋回流の特性一圧力 損失に及ほす旋回の影響一，ながれ，17-3（1998），202213.

（5）妹尾泰利・永田撤三，長い平滑管および粗面管の旋回流， 機論 (第 2 部), 38-308 (1972), 759-766.

(6) Baker, D. W. and Sayre, C. L., Decay of swirling turbulent flow of incompressible fluids in long pipe, Proc. Symp. Flow-Its Meas. Control Sci. Ind.-, Instrumental Society of America, (1974), 301-312.

（7）葦埜勲・前田茂，円管内の乱流旋回流の減衰，機論，50 460, B (1980), 3099-3106. 